НАУКОВИЙ ВІСНИК

Sientific messenger of Lviv National University

(a)

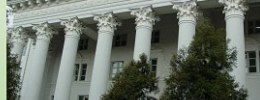

I. P. P

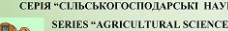

2020
Науковий вісник Дьвівського національного університету ветеринарної медицини та біотехнологій імені С.3. Гжицького. Серія: Сільськогосподарські науки

Scientific Messenger of Lviv National University of Veterinary Medicine and Biotechnologies. Series: Agricultural sciences

ISSN 2519-2698 print

doi: 10.32718/nvlvet-a9305

ISSN 2707-5834 online

https://nvlvet.com.ua/index.php/agriculture

UDC 636.27 (477).034.082.1: 567.316

\title{
Influence of seasonal changes on the karyotype stability of Ukrainian Black and White dairy cows
}

\author{
N. Y. Temekh, L. F. Starodub
}

Institute of Animal Breeding and Genetics nd. a. M. V. Zubets NAAS, Chubinskoe, Ukraine

Article info

Received 14.08.2020

Received in revised form 14.09.2020

Accepted 15.09.2020

Institute of Animal Breeding and Genetics nd. a. M. V. Zubets NAAS, Pogrebnyaka Str., 1, Chubinskoe, Boryspil district, Kiev region, 08321, Ukraine.

Tel.: +38-097-459-34-88

E-mail: starodublf@gmail.com
Temekh, N. Y., \& Starodub, L. F. (2020). Influence of seasonal changes on the karyotype stability of Ukrainian Black and White dairy cows. Scientific Messenger of Lviv National University of Veterinary Medicine and Biotechnologies. Series: Agricultural sciences, 22(93), $29-34$. doi: $10.32718 /$ nvlvet-a9305

Of the total dairy cattle, $49 \%$ belong to the Ukrainian black-and-white dairy breed. Animals are demanding to the conditions of detention, so the aim of the study was to study the impact of seasonal changes in the environment on the stability of the karyotype of cows of three age groups (first-born, adult and cows 8-10 years). The variability of the karyotype of the studied animals in different seasons of the year was manifested in the form of quantitative and structural disorders of chromosomes. Of the total dairy cattle, $49 \%$ belong to the Ukrainian black-and-white dairy breed. Animals are demanding to the conditions of detention, so the aim of the study was to study the impact of seasonal changes in the environment on the stability of the karyotype of cows of three age groups (first-born, adult and cows 8-10 years). The variability of the karyotype of the studied animals in different seasons of the year was manifested in the form of quantitative and structural disorders of chromosomes. In primiparous women, the most pronounced genomic variability (aneuploidy) was observed in summer and winter and was $16.4 \%$ and $8.8 \%$. In summer, this variability was more than twice the limit of spontaneous chromosomal variability. The highest percentage of structural chromosome abnormalities (chromosomal breaks) in cows of three age groups was observed in winter and was $2.5 \%, 2.8 \%, 3.0 \%$, respectively, and did not exceed the limit of spontaneous mutagenesis characteristic of cattle. An increased proportion of lymphocytes with a micronucleus in firstborns and cows aged 8-10 years (5.6\%, $6.4 \%$, respectively) was observed in the summer. The increased proportion of dinuclear lymphocytes appeared in the first-born in the summer season and amounted to $7.6 \%$ (at $P>0.99$ ), and in cows 8-10 years, this variability in the summer season was $6.2 \%$, in winter $6.7 \%$ with a statistically significant difference $(P>0.95)$ between the spontaneous level of cytogenetic variability. The association between karyotype stability of the studied animals and seasonal environmental factors was determined using a correlation coefficient ( $r$ ). A significant positive correlation was found between aneuploidy and air temperature in primiparous and cows aged 8-10 years, relative humidity, precipitation and wind strength and chromosomal gaps in primiparous and adult cows, atmospheric pressure, relative humidity and asynchronous divergence. in adult cows and cows aged 8-10 years. A positive reliable associative dependence of the appearance of micronucleus lymphocytes and dinuclear lymphocytes on the amount of precipitation and wind strength in this area in primiparous and adult cows was established.

Key words: Ukrainian Black and White dairy cows, karyotype, lymphocyte with micronucleus, dinuclear lymphocyte, correlation.

\section{Вплив сезонних змін на стабільність каріотипу корів української чорно- рябої молочної породи}

\author{
Н. Ю. Темех, Л. Ф. Стародуб
}

Інститут розведення і генетики тварин імені М. В. Зубия НААН, с. Чубинське, Київська область, Україна 
3 усього молочного поголів'я великої рогатої худоби українській чорно-рябій молочній породі належить 49 \%. Тварини вимогливі до умов утримання, тому метою роботи було дослідження впливу сезонних змін навколишнього середовища на стабільність каріотипу корів трьох вікових груп (первісток, повновікових та корів 8-10 років). Мінливість каріотипу досліджуваних тварин у різні сезони року проявилася у вигляді кількісних та структурних порушень хромосом. У первісток найбільш виражена геномна мінливість (анеуплоїдія) спостерігалася у літній та зимовий період і становила 16,4 \% та 8,8 \%. У літній період ия мінливість більше як у 2 рази перевищувала межу спонтанної хромосомної мінливості. Найвищий відсоток структурних порушень хромосом (хромосомні розриви) у корів трьох вікових груп спостерігався в зимовий період і становив 2,5\%, 2,8\%, 3,0\% відповідно та не перевищував межу спонтанного мутагенезу, характерного для великої рогатої худоби. Підвищена частка лімфоцитів із мікроядром у первісток та корів 8-10 років (5,6 \%о, 6,4 \%о відповідно) спостерігалася у літній період. Підвищена частка двоядерних лімфоцитів проявилася у первісток у літній сезон і становила 7,6 \%о (при P> 0,99), а в корів 8-10 років ия мінливість у літній сезон становила 6,2\%, в зимовий - 6,7\%о зі статистично вірогідною різницею $(P>0,95)$ між спонтанним рівнем цитогенетичноі мінливості. Встановлення асоційованого зв'язку між стабільністю каріотипу досліджуваних тварин $і$ сезонними факторами навколишнього середовища визначали за допомогою коефіцієнта корелячії (r). Додатню достовірну кореляцію виявлено між анеуплоїдією та температурою повітря у первісток та корів віком 8-10 років , відносною вологістю повітря, кількістю опадів та сили вітру і хромосомними розривами у первісток та повновікових корів, величиною атмосферного тиску, відносною вологістю повітря та асинхронним розходженням центромірних районів хромосом у повновікових корів та корів віком 8-10 років. Встановлено додатню достовірну асочіативну залежність появи лімфоцитів із мікроядром та двоядерних лімфоцитів від кількості опадів та сили вітру на иій території у первісток та повновікових корів.

Ключові слова: украӥнська чорно-ряба молочна порода, каріотип, лімфоцит із мікроядром, двоядерний лімфоцит, кореляційний зв'язок.

\section{Ветуп}

Наразі група чорно-рябих порід великої рогатої худоби найбільш поширена як у світі, так і в Україні (Poslavska et al., 2016; Shcherbatyj et al., 2017; Golub et al., 2018; Sachuk et al., 2019; Borshch et al., 2020; Slivinska et al., 2020). До цієї групи порід зачисляють голландську чорно-рябу, голштинську чорно-рябу США і Канади, українську чорно-рябу молочну та ін. Так, за даними Державної реєстраційної служби племінної справи у тваринництві станом на 01.01.2020 року всього в Україні є 387 молочних племінних стад, з яких 189 стад належать українській чорно-рябій молочній породі. 3 усього молочного племінного поголів'я (308,5 тис. гол., 3 яких дійних корів 133,5 тис.), 49 \% належить тваринам української чорно-рябої молочної породи (всього 152,5 тис. гол., дійних корів 66 тис.).

Українська чорно-ряба молочна порода була затверджена наприкінці 90-х років минулого століття в Україні (Efimenko et al., 2000). У породі об'єднали селекційні ознаки поліпшуючої голштинської худоби (високий надій молока), технологічність місцевої чорно-рябої породи (високі вміст жиру в молоці й плідність), добру пристосованість до місцевих умов утримання (Ruban \& Fedota, 2020). Частка спадковості поліпшувальної голштинської породи у структурі генотипу корів української чорно-рябої молочної породи у різних господарствах перебуває в межах 60 $75 \%, 85-95 \%$ і більше.

Голштинська порода корів досить вимоглива до умов утримання. Продуктивність безпосередньо залежить від раціону. 3 високою продуктивністю пов'язані й типові хвороби. Худоба не належить до групи довговічних тварин. Лише при відповідному догляді корови голштинської породи характеризуються як тварини із високим показником молочності, високою адаптацією до різних кліматичних умов та стійкістю до захворювань.

Метою роботи було дослідження впливу сезонних змін навколишнього середовища на стабільність каріотипу корів української чорно-рябої молочної породи.

\section{Матеріал і методи досліджень}

Дослідження проводили у господарстві СТзОВ “Прогрес плюс" с. Гаї Бродівського району Львівської області у корів української чорно-рябої молочної породи $(\mathrm{n}=30)$ трьох вікових груп (первістки, повновікові та тварини 8-10 років) з часткою кровності за голштинською породою понад 85 \%. Для встановлення асоційованого впливу факторів навколишнього середовища на каріотип досліджуваних тварин були взяті дані гідрометеорологічної служби України станції Броди Бродівського району Львівської області за 2017-2019 pp.

Цитогенетичні препарати готували згідно з традиційною методикою (Shelov \& Dzitsiuk, 2005). Забір крові проводили із яремної вени тварини. Для культивування клітин крові в лабораторії заготовляли стерильні флакони; фасували середовище RPMI-1640 з 15$20 \%$ - сироваткою крові великої рогатої худоби. До культури додавали антибіотик гентаміцин, а також мітоген - фітогемаглютинін типу Р та 0,5 мл цільної крові. Суміш культивували в термостаті при температурі $+37^{\circ} \mathrm{C}$ протягом 48 год. За дві години до фіксації в культуру вводили підігрітий до $37^{\circ} \mathrm{C}$ розчин колхіцину. Для гіпотонізації використовували свіжоприготовлений $0,55 \%$ розчин хлористого калію. Після закінчення гіпотонізації культуру центрифугували, надосадкову рідину зливали, а до осаду обережно по стінці пробірки додавали охолоджену до $+4 \mathrm{C}$ фіксуючу рідину, змішуючи одну частину льодяної оцтової кислоти з трьома частинами метилового (або етилового) спирту. Після цього осад ресуспендували i центрифугували, повторюючи цю операцію 2-3 рази. Суспензію клітин автоматичним дозатором із висоти 20-30 см наносили на чисті охолоджені предметні скельця. Висушували скло на повітрі. Отримані препарати після їхнього забарвлення аналізували на предмет хромосомної мінливості. У тварин визначали геномні мутації, пов'язані зі зміною числа хромосом у каріотипі (відсоток метафазних пластинок із анеуплоїдією (А), поліплоїдією (ПП), асинхронне розходження центромірних районів хромосом (АРЦРХ), а також 
структурні порушення (хромосомні та хроматидні розриви XP, XM).

У кожної тварини аналізували 100 метафазних пластинок. На тих самих препаратах підраховували кількість двоядерних лімфоцитів (ДЯ), одноядерних лімфоцитів із мікроядрами (МЯ), мітотичний індекс (МI). Частоту ДЯ, МЯ, МІ вираховували в проміле (кількість на 1000 клітин). (Рис. 1).

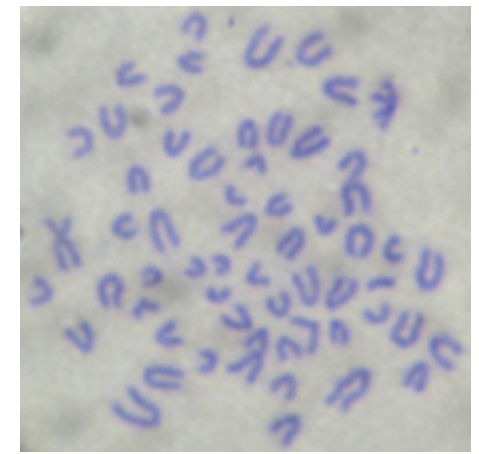

a

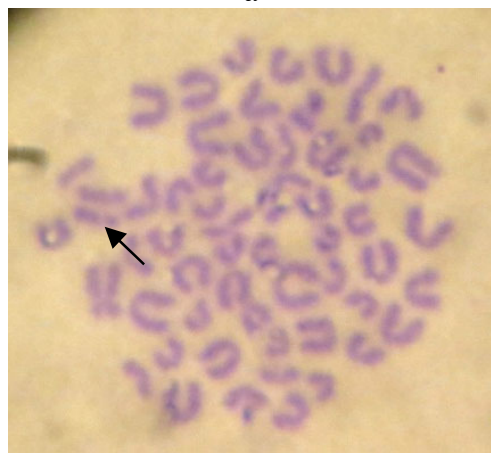

$\Gamma$

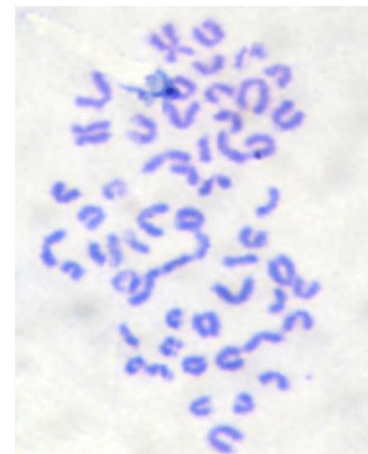

б

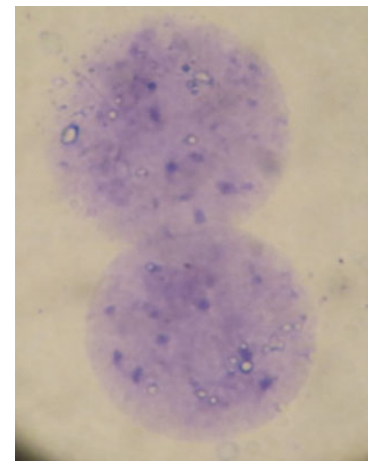

Д

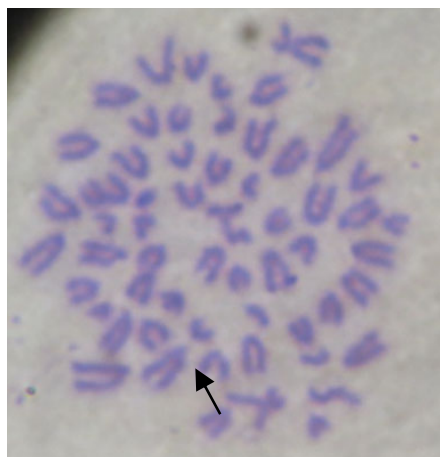

B

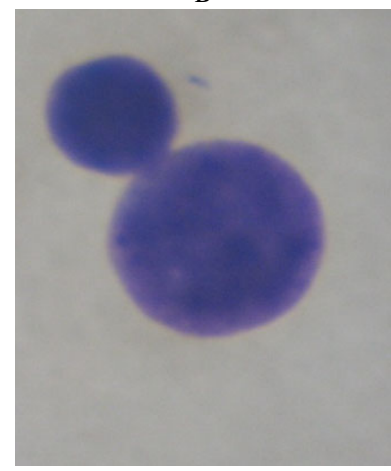

ж

Рис.1. Мінливість каріотипу корів української чорно-рябої молочної породи:

а) норма каріотипу $-2 \mathrm{n}=64$; б) анеуплоїдія $-2 \mathrm{n}=56$; в) хромосомний розрив;

г) асинхронне розходження центромірних районів X - хромосоми; д) двоядерний лімфоцит;

ж) лімфоцит із мікроядром;

\section{Результати та їх обговорення}

Результати цитогенетичного моніторингу корів української чорно-рябої молочної породи трьох вікових груп у різні сезони року показали, що для них характерні геномні та структурні порушення хромосом (табл. 1).

У первісток найбільш виражена геномна мінливість (анеуплоїдія), проявилася у літній та зимовий період і становила $16,4 \%$ та 8,8 \% відповідно. Відсоток цієї мінливості у літній період (16,4%) більше як у два рази перевищує межу спонтанної хромосомної мінливості (1,5-8,3\%) (Bashchenko et al., 2011), характерну для великої рогатої худоби при статистично достовірній різниці середніх величин (Р > 0,999). У повновікових корів та корів віком 8-10 років найвища частка клітин із анеуплоїдією спостерігалася у зимовий період і становила 9,9 \% та 5,9 \% відповідно, проте зі статистично невірогідною різницею середніх величин між спонтанним рівнем і проявленою мінливістю (Bashchenko et al., 2011).

Протягом всіх чотирьох сезонів асинхронне розходження центромірних районів хромосом у первісток не було виявлене. Відмінність цієї мінливості за сезонами у групах повновікових корів та корів 8-
10 років не спостерігалася і перебувала в межах $0,75 \%-2,1 \%$, що не перевищує рівня спонтанної хромосомної мінливості (4,5-13,4 \%) (Bashchenko et al., 2011).

Структурні порушення хромосом у тварин трьох вікових груп проявилися у вигляді хромосомних розривів. Найвищий відсоток цієї мінливості в досліджуваних тварин спостерігався у зимовий період і становив 2,5\%, 2,8\%, 3,0\% відповідно й не перевищував межу спонтанного мутагенезу, характерного для великої рогатої худоби (Bashchenko et al., 2011).

Для повнішої оцінки соматичного мутагенезу використовували мікроядерний тест. Результати проведеного тесту показали підвищену частку лімфоцитів із мікроядром (5,6 \%, 6,4 \%о відповідно) у первісток та корів 8-10 років у літній період із статистично невірогідною різницею середніх величин $(\lim 1,00-3,67$ \%о) за спонтанного мутагенезу (Dhus, 2012). Підвищена частка двоядерних лімфоцитів проявилася у первісток у літній сезон і становила 7,6 \%о (при Р >0,99), а в корів 8-10 років ця мінливість у літній сезон становила $6,2 \%$, в зимовий $-6,7 \%$ із статистично вірогідною різницею $(\mathrm{P}>0,95)$ між спонтанним рівнем цитогенетичної мінливості (Dhus, 2012). 


\section{Таблищя 1}

Каріотипова мінливість корів української чорно-рябої молочної породи трьох вікових груп у різні сезони року 3 часткою кровності за голштинською породою понад 85 \%

\begin{tabular}{|c|c|c|c|c|c|}
\hline Сезон & Анеуплоїдія, \% & $\begin{array}{l}\text { Хромосомні } \\
\text { розриви, \% }\end{array}$ & АРЦРХ,\% & $\begin{array}{c}\text { Лімфоцит із } \\
\text { мікроядром, \%о }\end{array}$ & $\begin{array}{c}\text { Двоядерний } \\
\text { лімфоцит, \%о }\end{array}$ \\
\hline \multicolumn{6}{|c|}{ Первістки $(\mathrm{n}=10)$} \\
\hline весна & & - & - & $5,0 \pm 1,47$ & $2,2 \pm 0,76$ \\
\hline літо & $16,4 \pm 2,41 * * *$ & $1,6 \pm 1,05$ & - & $5,6 \pm 2,13$ & $7,6 \pm 1,32 * *$ \\
\hline осінь & $1,3 \pm 0,57$ & $2,0 \pm 1,34$ & - & $4,2 \pm 1,56$ & $4,9 \pm 2,41$ \\
\hline зима & $8,8 \pm 3,78$ & $2,5 \pm 1,87$ & - & $4,5 \pm 0,51$ & $4,0 \pm 0,71$ \\
\hline \multicolumn{6}{|c|}{ Повновікові корови $(\mathrm{n}=10)$} \\
\hline весна & $2,0 \pm 1,10$ & $0,8 \pm 0,49$ & & $2,5 \pm 0,75$ & $3,0 \pm 0,99$ \\
\hline літо & $4,2 \pm 2,05$ & - & $0,75 \pm 0,60$ & $3,5 \pm 1,05$ & $4,3 \pm 0,29$ \\
\hline осінь & $3,1 \pm 1,53$ & $1,5 \pm 0,76$ & - & $2,7 \pm 1,82$ & $3,0 \pm 1,91$ \\
\hline зима & $9,9 \pm 3,41$ & $2,8 \pm 1,29$ & $1,6 \pm 1,58$ & $4,5 \pm 1,00$ & $3,0 \pm 1,41$ \\
\hline \multicolumn{6}{|c|}{ Корови віком 8-10 p., $(\mathrm{n}=10)$} \\
\hline весна & $2,9 \pm 0,56$ & $0,76 \pm 0,42$ & - & $4,0 \pm 2,75$ & $3,0 \pm 1,35$ \\
\hline літо & $3,0 \pm 0,94$ & $2,0 \pm 1,99$ & $1,0 \pm 0,99$ & $6,4 \pm 1,10$ & $6,2 \pm 1,29 *$ \\
\hline осінь & $3,8 \pm 2,10$ & $1,5 \pm 0,96$ & - & $3,8 \pm 0,56$ & $4,5 \pm 1,03$ \\
\hline зима & $5,9 \pm 2,00$ & $3,0 \pm 1,38$ & $2,1 \pm 1,70$ & $5,0 \pm 1,01$ & $6,7 \pm 1,02 *$ \\
\hline
\end{tabular}

Примітка: *_P >0,95; **-P >0,99; ***-P >0,999

Таблиця 2

Середні значення метеорологічних і агрометричних спостережень за 2017-2019 роки станції Броди Львівської області

\begin{tabular}{|c|c|c|c|c|c|}
\hline Рік & $\begin{array}{c}\text { Середня } \mathrm{t}^{\circ} \\
\text { повітря }\end{array}$ & $\begin{array}{c}\text { Відносна вологість } \\
\text { повітря, } \%\end{array}$ & $\begin{array}{c}\text { Опади } \\
\text { мм/на місяць }\end{array}$ & $\begin{array}{c}\text { Атмосферний тиск,мм } \\
\text { рт. ст./бар }\end{array}$ & $\begin{array}{c}\text { Biтep } \\
\mathrm{M} / \mathrm{c}\end{array}$ \\
\hline \multicolumn{6}{|c|}{ Зима } \\
\hline 2017 & $-3,4$ & 78,0 & 0,8 & 740,3 & 2,7 \\
\hline 2018 & $-0,8$ & 83,3 & 1,5 & 757,9 & 2,4 \\
\hline 2019 & $-1,1$ & 82,3 & 1,8 & 750,0 & 2,8 \\
\hline $\mathrm{M} \pm \mathrm{m}$ & $-1,8 \pm 1,01$ & $81,2 \pm 2,00$ & $1,4 \pm 0,36$ & $\begin{array}{c}749,4 \pm 6,29 \\
\text { 0,99 Бар }\end{array}$ & $2,6 \pm 0,14$ \\
\hline \multicolumn{6}{|c|}{ Весна } \\
\hline 2017 & 9,6 & 71,7 & 1,5 & 740,3 & 2,6 \\
\hline 2018 & 10,4 & 70,0 & 1,7 & 740,2 & 2,2 \\
\hline 2019 & 9,7 & 70,0 & 2,6 & 741,7 & 2,3 \\
\hline $\mathrm{M} \pm \mathrm{m}$ & $9,9 \pm 0,31$ & $70,6 \pm 1,37$ & $1,9 \pm 0,41$ & $\begin{array}{c}740,7 \pm 0,59 \\
0,98 \text { Бар }\end{array}$ & $2,4 \pm 0,14$ \\
\hline \multicolumn{6}{|c|}{ Літо } \\
\hline 2017 & 19,2 & 71,6 & 2,2 & 728,7 & 2,0 \\
\hline 2018 & 19,5 & 75,0 & 3,1 & 740,7 & 1,9 \\
\hline 2019 & 19,9 & 71,3 & 1,9 & 744,8 & 1,9 \\
\hline $\mathrm{M} \pm \mathrm{m}$ & $19,5 \pm 0,29$ & $72,6 \pm 1,46$ & $2,4 \pm 0,44$ & $\begin{array}{c}738,1 \pm 5,97 \\
0,98 \text { Бар }\end{array}$ & $1,9 \pm 0,03$ \\
\hline \multicolumn{6}{|c|}{ Oсінь } \\
\hline 2017 & 9,2 & 81,6 & 2,5 & 741,8 & 2,9 \\
\hline 2018 & 9,5 & 79,3 & 1,2 & 733,5 & 2,4 \\
\hline 2019 & 10,8 & 77,3 & 0,85 & 725,6 & 2,4 \\
\hline $\mathrm{M} \pm \mathrm{m}$ & $9,8 \pm 0,60$ & $79,4 \pm 1,57$ & $1,5 \pm 0,61$ & $\begin{array}{c}733,6 \pm 5,78 \\
0,97 \text { Бар } \\
\end{array}$ & $2,6 \pm 0,20$ \\
\hline
\end{tabular}

Для встановлення асоційованого ступеня зв'язку між стабільністю каріотипу і сезонними факторами навколишнього середовища були взяті дані гідрометеорологічної служби України станції Броди Бродівського району Львівської області за 2017-2019 pp. (табл. 2).

Ступінь зв'язку між стабільністю каріотипу досліджуваних тварин і сезонними факторами навколиш- нього середовища визначали за допомогою коефіцієнта кореляції (r) (Табл. 3).

Дані таблиці показують, що у первісток найбільш додатній достовірний $(\mathrm{P}>0,95)$ зв'язок встановлений між анеуплоїдією і температурою повітря, відносною вологістю повітря та хромосомними розривами $(\mathrm{P}>0,99)$, лімфоцитами із мікроядром як показником генотоксичного впливу та кількістю опадів $(\mathrm{P}>0,999)$. 
Таблиця 3

Кореляційний зв'язок між стабільністю каріотипу корів української чорно-рябої молочної породи трьох вікових груп та сезонними факторами навколишнього середовища

\begin{tabular}{|c|c|c|c|c|c|}
\hline \multirow{2}{*}{$\begin{array}{c}\text { Корелюючі } \\
\text { ознаки }\end{array}$} & \multicolumn{5}{|c|}{ Хромосомні порушення } \\
\hline & Анеуплоїдія & $\begin{array}{c}\text { Хромосомні } \\
\text { розриви }\end{array}$ & АРЦРХ & $\begin{array}{l}\text { Лімфоцит із } \\
\text { мікроядром }\end{array}$ & $\begin{array}{c}\text { Двоядерний } \\
\text { лімфоцит }\end{array}$ \\
\hline \multicolumn{6}{|c|}{ Первістки } \\
\hline $\mathrm{t}^{\circ}$ повітря & $0,5823 *$ & 0,3396 & - & 0,7321 & 0,6465 \\
\hline Відносна вологість повітря, \% & 0,0364 & $0,8793 * *$ & - & 0,7820 & 0,0194 \\
\hline Опади мм/на місяць & 0,5734 & 0,4340 & - & $0,9568 * * *$ & 0,5573 \\
\hline Атмосфер. тиск, бар & 0,4038 & 0,1888 & - & 0,1998 & 0,1633 \\
\hline Вітер, м/с & 0,7340 & 0,2356 & - & 0,4649 & 0,3329 \\
\hline \multicolumn{6}{|c|}{ Повновікові корови } \\
\hline $\mathrm{t}^{\circ}$ повітря & 0,5311 & 0,9698 & 0,7109 & 0,5048 & 0,7783 \\
\hline Відносна вологість повітря, \% & 0,6987 & 0,8517 & $0,9998 * * *$ & 0,5590 & 0,4344 \\
\hline Опади & 0,4525 & $0,9203 * *$ & 0,8163 & 0,2097 & $0,8799 *$ \\
\hline \multicolumn{6}{|l|}{ мм/на місяць } \\
\hline Атмосфер. тиск, бар & 0,7894 & 0,4471 & 0,1567 & 0,8082 & 0,0000 \\
\hline Вітер, м/с & 0,2811 & $0,8392 * *$ & 0,6772 & 0,0222 & $0,9584 * * *$ \\
\hline \multicolumn{6}{|c|}{ Корови віком 8-10 років } \\
\hline $\mathrm{t}^{\circ}$ повітря & 0,8784 & 0,4882 & 0,5041 & 0,4248 & 0,1809 \\
\hline Відносна вологість повітря, \% & $0,8620 *$ & 0,7007 & 0,4969 & 0,1898 & 0,5333 \\
\hline Опади, мм/на місяць & 0,7423 & 0,2917 & 0,1758 & 0,6784 & 0,0043 \\
\hline Атмосфер. тиск, бар & 0,6155 & 0,6515 & $0,8583 *$ & 0,4121 & 0,5323 \\
\hline Вiтер, м/c & 0,6012 & 0,0875 & 0,0025 & 0,8147 & 0,2093 \\
\hline
\end{tabular}

Примітка: *-P >0,95; **-P >0,99; ***-P >0,999

У повновікових корів поява хромосомних розривів, асинхронного розходження центромірних районів хромосом та виникнення двоядерних лімфоцитів асоційовано може залежати від кількості опадів, відносної вологості повітря та сили вітру на цій території.

Асоціація зв'язку між факторами навколишнього середовища та хромосомними порушеннями спостерігалася і в корів віком 8-10 років. Так, додатній достовірний зв'язок був виявлений між анеуплоїдією та відносною температурою повітря (Р > 0,95), асинхронним розходженням центромірних районів хромосом та атмосферним тиском $(\mathrm{P}>0,95)$.

\section{Висновки}

Досліджено каріотипову мінливість корів української чорно-рябої молочної породи трьох вікових груп у різні сезони року та встановлені кількісні та структурні порушення хромосом.

Встановлено найбільш виражену (більше як у 2 рази перевищує межу спонтанної хромосомної мінливості) геномну мінливість (анеуплоїдію) у первісток у літній період.

Найвищий відсоток структурних порушень хромосом (хромосомні розриви), що не перевищує межу спонтанного мутагенезу в корів трьох вікових груп, визначено у зимовий період.

Встановлено вірогідно підвищену частку двоядерних лімфоцитів у первісток у літній період при $\mathrm{P}>0,99$, а в корів 8-10років у літній та зимовий період при $\mathrm{P}>0,95$.

Додатну достовірну кореляцію виявлено між анеуплоїдією та температурою повітря у первісток та корів віком 8-10 років, відносною вологістю повітря, кількістю опадів та сили вітру і хромосомними розри- вами у первісток та повновікових корів, величиною атмосферного тиску, відносною вологістю повітря та асинхронним розходженням центромірних районів хромосом у повновікових корів та корів віком 8-10 років.

Встановлено додатну достовірну асоціативну залежність появи лімфоцитів із мікроядром та двоядерних лімфоцитів у первісток та повновікових корів від кількості опадів та сили вітру на цій території.

\section{References}

Bashchenko, M. I., Kopylov, K. V., Dobrianska, M. L., Starodub, L. F., Podoba, Yu. V., \& Kopylova, K. V. (2011). Vyznachennia henetychnykh anomalii u velykoi rohatoi khudoby: metodychni rekomendatsii, Instytut rozvedennia i henetyky tvaryn NAAN, Chubynske (in Ukrainian).

Borshch, O. O., Gutyj, B. V., Sobolev, O. I., Borshch, O. V., Ruban, S. Yu., Bilkevich, V. V., Dutka, V. R., Chernenko, O. M., Zhelavskyi, M. M., \& Nahirniak, T. (2020). Adaptation strategy of different cow genotypes to the voluntary milking system. Ukrainian Journal of Ecology, 10(1), 145-150. doi: $10.15421 / 2020 \_23$.

Dhus, P. P. (2012) Vydospetsyfichnist destabilizatsii kariotypiv silskohospodarskykh tvaryn za radiatsiinoho ta infektsiinoho vplyvu. Avtoref. dys. na zdobuttia nauk. stupenia kand. biol. nauk: spets. 03.00.15 "Henetyka". K. (in Ukrainian).

Efimenko, M. I., Burkat, V. P., Kostenko, O. I., \& Kholkin, M. M. (2000). Ukrainska chorno-riaba molochna poroda velykoi rohatoi khudoby. Selektsiini dosiahnennia u tvarynnytstvi. Kyiv, Ahrar. nauka, 3-4 (in Ukrainian). 
Golub, O., Shalovylo, S., Bojko, A., \& Oseredchuk, R. (2018). Extraterritorial-constitutional features of Black-and-Spotted Dairy cows of different affinity and production types. Scientific Messenger of LNU of Veterinary Medicine and Biotechnologies. Series: Agricultural $\quad$ Sciences, 20(89), 41-46. doi: 10.32718/nvlvet8907.

Poslavska, Y., Fedorovych, E., \& Bodnar, P. (2016). Features of growth of the living mass of different ukrainian black-spotted lines dairy cows breed during the period of their breeding. Scientific Messenger of LNU of Veterinary Medicine and Biotechnologies. Series: Agricultural Sciences, 18(2), 199-203. doi: $10.15421 /$ nvlvet6744.

Ruban, S., \& Fedota, O. (2020). Poroda yak osnovnyi faktor prybutkovoho molochnoho skotarstva. Agroexpert, 05(5), 142 (in Ukrainian).

Sachuk, R., Stravsky, Y., Shevchenko, A., Katsaraba, O., Kostyshyn, Y., \& Zhyhalyuk, S. (2019). Distribution, etiology and prevention of subclinical mastitis in cows.
Ukrainian Journal of Veterinary and Agricultural Sciences, 2(2), 18-21. doi: 10.32718/ujvas2-2.04.

Shcherbatyj, Z., Bodnar, P., \& Kropyvka, Y. (2017). Milk productivity and reproductive ability of ukrainian black-spotted dairy breed cows of different type of constitution. Scientific Messenger of LNU of Veterinary Medicine and Biotechnologies. Series: Agricultural Sciences, 19(74), 182-187. doi: $10.15421 /$ nvlvet7440.

Shelov, A. V., \& Dzitsiuk, V. V. (2005). Metodyka pryhotuvannia metafaznykh khromosom limfotsytiv peryferiinoi krovi tvaryn. Metodyky naukovykh doslidzhen iz selektsii, henetyky ta biotekhnolohii u tvarynnytstvi. Kyiv: Ahrarna nauka (in Ukrainian).

Slivinska, L. G., Shcherbatyy, A. R., Lukashchuk, B. O., \& Gutyj, B. V. (2020). The state of antioxidant protection system in cows under the influence of heavy metals. Regulatory Mechanisms in Biosystems, 11(2), 237-242. doi: 10.15421/022035. 